\title{
Impact of Fusarium Head Blight in Reducing the Weight of Oat Grains
}

\author{
José Antônio Martinelli ${ }^{1}$, Márcia Soares Chaves ${ }^{2}$, Felipe André Sganzerla Graichen ${ }^{3}$, Luiz Carlos Federizzi ${ }^{4}$ \& \\ Luiz Felipe Dresch ${ }^{5}$ \\ ${ }^{1}$ Departamento de Fitossanidade, Universidade Federal do Rio Grande do Sul, Porto Alegre, Brazil \\ ${ }^{2}$ EMBRAPA-Trigo, Passo Fundo, Brazil \\ ${ }^{3}$ Universidade Estadual do Mato Grosso do Sul, Aquidauana, Brazil \\ ${ }^{4}$ Departamento de Plantas de Lavoura, Universidade Federal do Rio Grande do Sul, Porto Alegre, Brazil \\ ${ }^{5}$ Bayer Crop Science, Porto Alegre, Brazil \\ Correspondence: José Antônio Martinelli, Departamento de Fitossanidade, Universidade Federal do Rio Grande \\ do Sul, Av. Bento Gonçalves 7712, Porto Alegre 91540-000, RS, Brazil. E-mail: jamfito@ufrgs.br
}

Received: February 28, 2014 Accepted: March 21, 2014 Online Published: April 25, 2014

doi:10.5539/jas.v6n5p188 URL: http://dx.doi.org/10.5539/jas.v6n5p188

\begin{abstract}
Fusarium head blight (FHB or scab) is caused by the fungus Fusarium graminearum (teleomorph Gibberella zeae) and has emerged during the last few decades as one of the major threats to cereal production, with the steady increase in the incidence of this pathogen having led to severe quantitative and qualitative damage. For oats, unlike other winter cereals such as wheat or barley, there is little information regarding yield losses due to $\mathrm{FHB}$. We field-evaluated 15 different oat genotypes with or without FHB on their panicles and treated or untreated with fungicide. For each genotype, 300 ripe panicles per treatment were hand harvested, individually threshed and weighed to estimate the weight of grain produced and correlate this with FHB genotype resistance. Damage caused by the disease was calculated by subtracting the observed yield from the potential yield. When untreated with fungicide, no genotype showed complete immunity to FHB but the average potential grain weight loss for the 15 oat genotypes was small (3.29\%), although five genotypes did show significantly reduced grain weight when infected with FHB. Fungicide treatment significantly reduced the percentage of infected spikelets and grain weight loss for the majority of genotypes. Although the data showed relatively small grain weight losses due to FHB, there was no genotype with complete immunity to this pathogen. It appears that continuous no-tillage may influence the incidence of FHB on oats and should be carefully monitored in the field.
\end{abstract}

Keywords: Avena sativa, Gibberella zeae, scab, resistance, chemical control

\section{Introduction}

In southern Brazil during the last few decades, oats (Avena sativa L.) have become an excellent option for the winter/spring cultivation season after the major summer crops, such as maize and soybeans (Silva, Martinelli, Federizzi, Chaves, \& Pacheco, 2012). However, the favourable environmental conditions, principally high humidity, occurring during winter and spring means that oat crops can be attacked by many pathogens, with Fusarium head blight (FHB or scab) having recently become a much more frequent problem.

Oat scab is a global disease caused by a number of anamorphic Fusarium species, with Fusarium graminearum Schwabe (teleomorph Gibberella zeae (Schwein.) Petch) dominating in North America (McMullen, Jones, \& Gallenberg, 1997). In Canada, for example, the most prevalent species are Fusarium graminearum, Fusarium avenaceum, Fusarium sporotrichioides and Fusarium poae (Tekauz, Mitchell Fetch, Rossnagel, \& Savard, 2008; Tamburic-Ilincic, 2010). In the cooler climate of northern Europe, however, the species that predominate are not only $F$. graminearum, $F$. avenaceum and $F$. poae but also Fusarium culmorum and Fusarium tricinctum (Yli-Mattila, 2010). In South America, there is little information available regarding the effects of Fusarium species on the weight of oat grains, although $F$. graminearum has been reported to be the primary species associated with FHB of small grains such as barley, triticale and wheat. Other Fusarium species such as avenaceum, culmorum, poae, equiseti, acuminatum, trincictum, sambucinum, semitectum and chlamydosporum 
have also been reported to infect these small grains in minor frequencies (Angelotti et al., 2006; Pereyra \& Dill-Macky, 2010).

The predominant system of crop cultivation in southern Brazil is direct sowing, also known as no-tillage. However, this type of cultivation promotes the survival and proliferation of pathogens such as $F$. graminearum and can result in an increase in the incidence and severity of disease (Fernandez, Fernandes, \& Sutton, 1993). In the case of $F$. graminearum, this fungus survives between growing seasons as a saprophyte on host and non-host crop residues left on the surface, producing easily and widely dispersible conidia and ascospores which are released and dispersed by wind and rain and can be carried long distances from their source. The increased area of no-tillage maize (Zea mays) has made corn debris colonized with $F$. graminearum one of the primary and most important sources of FHB inoculum for winter cereals growing in southern Brazil (Casa et al., 2000). In addition to maize, a wide range of plant species can also serve as the host for F. graminearum (Reis, 1986; Goswami \& Kistler, 2004), with these alternative hosts having, in most cases, also benefited from the no-tillage system and thus contributed to the increased density of the $F$. graminearum inoculum.

The first symptoms of FHB were reported on non-extruded wheat anthers (Pugh, Johann, \& Dickson, 1933; Strange \& Smith, 1971), and it has been generally thought that the higher affinity of Fusarium for anthers occurs because Fusarium is a successful saprophyte and, after anthesis, anthers constitute dead tissue. The prolific growth of $F$. graminearum on anthers has been reported to be due to the fungal growth stimulants betaine and choline, which are more concentrated in anthers than other parts of the floret (Strange, Majer, \& Smith, 1974).

Recent research suggests that $F$. graminearum enters oat plants primarily through the floret apex and the floret cavity, where it infects the internal surfaces of the palea, lemma and caryopsis, with hyphae growing more profusely on the anthers than other floret parts during the initial stages of infection (Tekle, Dill-Macky, Skinnes, Tronsmo, \& Bjørnstad, 2012). As the infection process progresses, the characteristic symptoms of FHB begin to appear as unpigmented, whitish or pale spikelets, which contrast with the normal green and healthy spikes. Under favorable conditions, signs of the pathogen can be readily observed on affected spikelets, which are salmon-pink at the bottom and the edges of glumes (Brown, Urban, Van de Meene, \& Hammond-Kosack, 2010).

In the southern Brazilian states of Paraná, Santa Catarina and Rio Grande do Sul the environmental conditions conducive to the development of wheat FHB are well known, this disease being so important that there is an alert system for risk assessment that releases alert information based mainly on climatic elements such as temperature, precipitation and relative humidity (http://mosaico.upf.br/ sisalert/monitoramento/giberela). For oats growing at the same states, we have observed, over a period of about ten years, that FHB appears especially where high rainfall occurs for more than 48 hours consecutively during, or soon after, anthesis, and when the temperature lies between $20^{\circ} \mathrm{C}$ and $25^{\circ} \mathrm{C}$ and the relative humidity is above $90 \%$.

The damage caused by FHB on cereals can be quantitative and qualitative (Mauler-Machnik \& Zahn, 1994; Parry, Jenkinson, \& McLeod, 1995; Tekle, Skinnes, \& Bjørnstad, 2013), resulting in reduced germination and the production of mycotoxins (Tekle, Skinnes, \& Bjørnstad, 2013; Tekle, Dill-Macky, Skinnes, Tronsmo, \& Bjørnstad, 2012). Secondary damage can manifest as a reduction in the protein content of the grain (Mauler-Machnik \& Zahn, 1994; Mesterházy \& Bartok, 1996) and decreased germination and seed vigor (Teckle et al., 2013). Damage may vary in relation to the oat species and variety concerned and the year and the prevailing environmental condition. In southern Brazil, average yield losses due to FHB have been reported to be about $8 \%$ on barley, $17 \%$ on wheat and $44 \%$ on rye (Panisson, Reis, \& Boller, 2003). Although reduced yields due to FHB is known to occur in wheat and barley growing in other regions of the world (McMullen et al., 1997) no accurate studies on FHB damage in oat have as yet been reported.

Control measures for FHB depend on not only on the adoption of more resistant cultivars but also the use of crop rotation with or without the application of fungicides (Pirgozliev, Edwards, Hare, \& Jenkinson, 2003). Nevertheless, FHB can still have devastating effects on the production of winter cereals because when conditions are favorable for the pathogen the efficiency of fungicides is relatively low and dependent on the time of application and the genetic resistance of a cultivar may be insufficient to impede infection (Reis, Panisson, \& Boller, 2002).

Studies regarding the possible sources of FHB resistance in oats have yet to be developed and no oat cultivars are presently immune to scab, most oat cultivars being classified as FHB susceptible or, at most, moderately resistant. We evaluated a number of oat genotypes for reduced grain yield due to FHB infection and investigated the possibility of using such reductions to differentiate between the various levels of resistance occurring in these genotypes. 


\section{Method}

The experiments took place at the Agricultural Experimental Station, Agronomy Faculty, Federal University of Rio Grande do Sul (Estação Experimental Agronômica (EEA), Faculdade de Agronomia, Universidade Federal do Rio Grande do Sul (UFRGS) - EEA/UFRGS), Eldorado do Sul, Rio Grande do Sul (30 05' 52" S, 51 39' $08^{\prime \prime} \mathrm{S}$, elevation $\approx 46 \mathrm{~m}$ ). The climate at the site is classified as $C f a$, subtropical humid with hot summers and rainfall well distributed throughout the year, (Bergamaschi, Guadagnin, Cardoso, \& Silva, 2003). The soil is a typical Dystrophic Red with sandy texture at the surface (Streck et al., 2002). The experiment was established in an area under no-tillage in succession to maize.

In June 2003 and 2004, winter in the Southern Hemisphere, we planted 15 different oat genotypes (Table 1) to evaluate them for susceptibility to FHB and the damage caused by this disease. All standard recommended procedures for oat cultivation were used and the plants were allowed to undergo natural inoculation with the Fusarium present in the environment. The experimental design was a randomized block with a $15 \times 2$ factorial scheme consisting of 15 genotypes and two treatments (with or without application of fungicide at the flowering stage) and three replicate plots each consisting of five $3 \mathrm{~m}$ rows $0.2 \mathrm{~m}$ apart sown at a density of 300 seeds $\mathrm{m}^{-2}$. For the treatment with fungicide, we applied Opera ${ }^{\circledR}$ (BASF, Brazil), containing $85 \mathrm{~g} \mathrm{~L}^{-1}$ pyraclostrobin and $62.5 \mathrm{~g} \mathrm{~L}^{-1}$ epoxiconazole, at the rate of $0.6 \mathrm{~L} \mathrm{ha}^{-1}$ using a backpack sprayer pressurized with $\mathrm{CO}_{2}$. The fungicide was sprayed at 50\% anthesis, then at growth stage 69 (Zadoks, Chang, \& Konzak, 1974) and seven days after, depending on the date of flowering of each cultivar group.

Table 1. Genotypes sown in the field in 2003 and in 2004 and their genealogy.

\begin{tabular}{ll}
\hline \multicolumn{1}{c}{ Genotype } & \multicolumn{1}{c}{ Genealogy } \\
\hline UFRGS 9912003-2 & UFRGS 86A1194-2 / UFRGS 8 \\
URS 21 & UFRGS 10 x CTC 84B993 \\
OR2 & Unknown \\
UFRGS 995034-3 & PC68/5*STARTER F4 x UFRGS 8 \\
UFRGS 995090-2 & UFRGS 881971//PC68/5*STARTER F4 \\
UTFB 9702 & Unknown \\
URS 22 & UFRGS 841110 x UFRGS 884021-1 \\
UFRGS 881971 & Cocker 81C42 // Coronado2 / Cortez3 / Pendek / ME1563 \\
UFRGS 995036-1 & PC68/5*STARTER F4 x UFRGS 8 \\
UFRGS 999003-2 & UFRGS 7 X UFRGS 881920 \\
UPF 92151 & UFRGS 884110 / CTC 84B993 \\
UFRGS 14 & 80SA65 // Coronado2 / Cortez3 / Pendek / Me 1563 \\
Micronuda & Unknown \\
UFRGS 19 & UFRGS 841110 x UFRGS 884021-1 \\
UFRGS 996065-5 & UPF85380-a-2/94 6H35 (TAMO 386 ERB/92SAT24-4 \\
\hline
\end{tabular}

In September 2003 and 2004, spring in the Southern Hemisphere, the incidence of FHB was evaluated 15 days after spraying with fungicide when the plants were at the soft dough stage, stage 85 according to Zadoks et al. (1974). In 2003 the environmental conditions were unfavorable for the development of FHB (Figure 1), but in 2004 the conditions were ideal for FHB (Figure 1), as seen by the presence of white or pink spikelets in contrast to the normal, healthy, green spikes.

For each treatment (with and without fungicide) and each of the three replicate field plots, we marked 50 healthy panicles and 50 diseased panicles (with at least one spikelet showing symptoms of FHB) per genotype. Thus, for each genotype, 300 panicles were marked per treatment, giving a total of 600 panicles per genotype.

After maturation, the marked panicles were harvested, manually threshed, and the healthy and diseased spikelets and grains separated and counted. The total grain weight obtained from healthy and diseased spikelets was quantified using an analytical balance and were expressed as spikelets per panicle and grain weight per panicle (g panicle $^{-1}$. 
Data from only untreated and treated diseased panicles were used to determined damage according to the method of Reis (1986), with some modifications. In brief, the potential yield (PY) was calculated as the total weight of grains from the healthy spikelets (WHS) divided by the number of grains in the healthy spikelets (NKHS) and multiplied by the total number (healthy plus diseased) of grains (TNK) in all the spikelets using the formula PY = WHS/NKHS x TNK. The observed yield (OY) was calculated as the sum of the weight of healthy grains (WHK) plus the weight of diseased grains (WDK) per individual panicle as OY=WHK + WDK. Potential Damage (PD) was estimated by subtracting the observed yield from the potential yield as PD $=\mathrm{PY}-\mathrm{OY}$.

The data collected were subjected to analysis of variance (ANOVA) and the treatments discriminated using Tukey's test at $\mathrm{P}=5 \%$, using the SOC statistical program (EMBRAPA, 1990). The weight of grains in each panicle was analyzed using a $15 \times 2 \times 2$ factorial scheme (15 genotypes, with or without fungicide, and panicles with or without FHB). The other variables, PY, OY and PD, were evaluated only in panicles with FHB, using a 15 x 2 factorial scheme (15 genotypes, with or without fungicide). The values regarding the percentage of infected spikelets were subjected to an arcsine transformation before statistical analysis.

The relationship between potential damage and potential yield was estimated using Pearson's correlation analysis and a biplot graph of these two variables (Figure 2), the data being subdivided into quartiles based on the median value, where quartile A indicated high damage and reduced potential yield, quartile B high damage and potential yield, quartile $\mathrm{C}$ reduced damage and potential yield, and quartile $\mathrm{D}$ reduced damage and high potential yield.

A

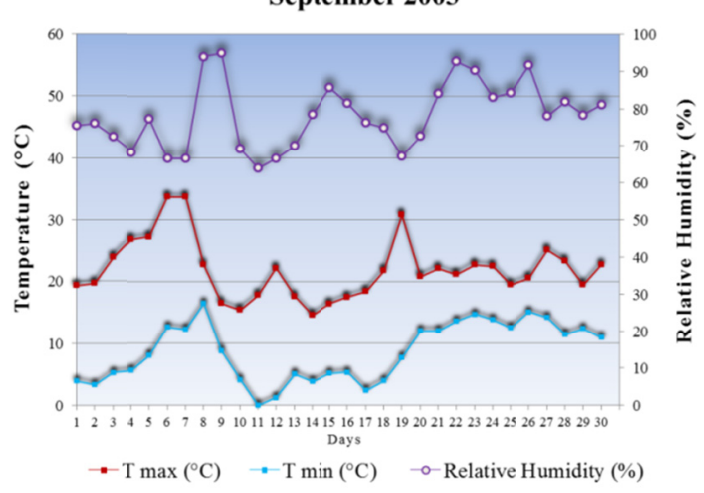

B

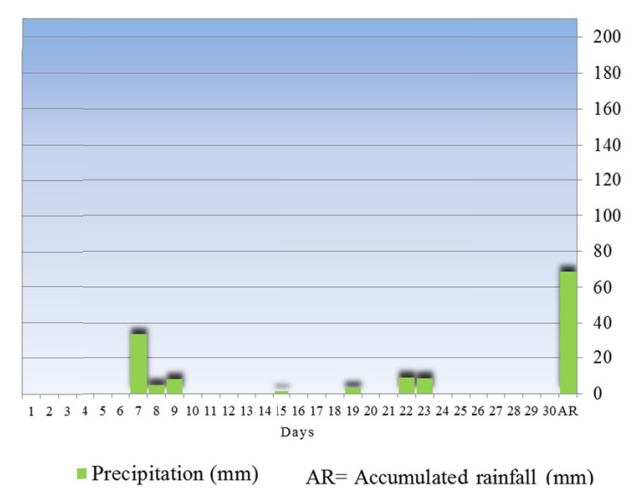

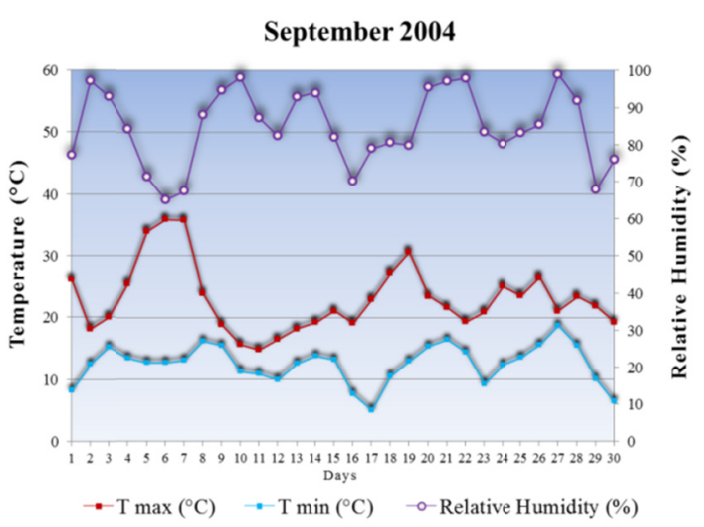

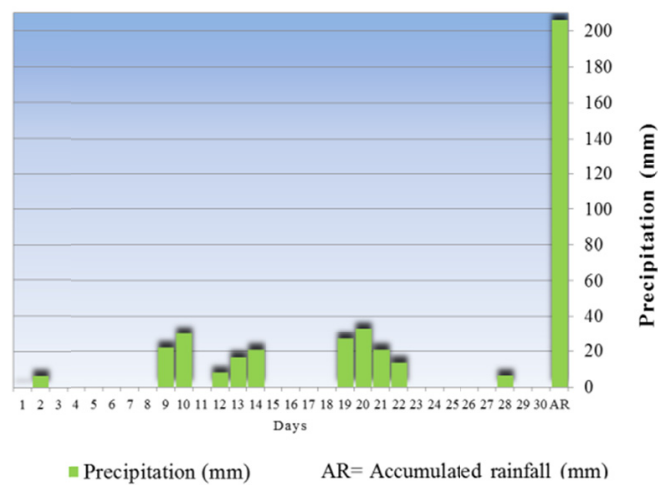

Figure 1. A comparative daily maximal and minimal temperatures $\left({ }^{\circ} \mathrm{C}\right)$, relative humidity $(\%)$ and precipitation (mm) during the months of September 2003 and September 2004

\section{Results}

In 2003 the environmental conditions were unfavorable for the occurrence of FHB (Figure 1) and the experiment to determine oat losses in that year did not produce enough data to analysis and compare genotypes.

September 2004, when anthesis and grain formation occurred, was humid and rainy and therefore very favorable to FHB. The accumulated rainfall was $206 \mathrm{~mm}$, which occurred in prolonged periods of rainfall of $48 \mathrm{~h}$ or more and 
coincided with eleven days of temperatures above $20{ }^{\circ} \mathrm{C}$ and relative humidity's in excess of $90 \%$ (www.ufrgs.br/agronomia/joomla/index.php/eea-pesquisa ) (Figure 1).

Analysis of variance for the weight of grains per panicle showed no significant effect for the triple interaction genotype $x$ fungicide $x \mathrm{FHB}(\mathrm{P}>\mathrm{F}=0.811)$ nor for two of the double interactions genotype $x$ fungicide $(\mathrm{P}>\mathrm{F}=0.318)$ and fungicide $x$ FHB $(P>F=0.965)$, the only significant double interaction being genotype $x$ FHB $(P>F=0.001)$. The single effects of the three factors were also significant $(\mathrm{P}>\mathrm{F}=0.0001)$, with the analysis of the variation between the treatments for the weight of grains per panicle, which was significant by Tukey's test at $\mathrm{P}=5 \%$ based on $i$ ) the comparison of the genotypes between themselves for each individual situation with and without FHB, ii) the comparison of the disease, its presence or absence, on each individual genotype and iii) the simple effect of the treatment with fungicide on the weight of grains per panicle (Table 2). The weight of grains per panicle with FHB ranged from $1.356 \mathrm{~g}$ for genotype UFRGS 19 to $2.732 \mathrm{~g}$ for genotype UFRGS 9912003-2 (Table 2). However, the weight of grains per panicle without FHB ranged from $1.538 \mathrm{~g}$ for genotype Micronuda to $3.209 \mathrm{~g}$ for UFRGS 9912003-2 (Table 2). The presence of FHB on panicles resulted in a significant reduction in grain weight of between $19.60 \%$ and $36.69 \%$ for only the five genotypes UTFB 9702, UFRGS 995034-3, UFRGS 881971, OR 2 and URS 22 (Table 2). Application of fungicide resulted in a greater weight of grains per panicle (Table 2) due to the decrease in infected spikelets (Table 3).

For the incidence of FHB on oat cultivars, there was a significant effect for the interaction between the genotypes and the treatment with fungicide as well as for the simple effects of both factors $(\mathrm{P}=>0.0001)$. The variation between treatments for the percentage of infected spikelets, which was significant by the by Tukey's test at $\mathrm{P}=$ $5 \%$, was carried out as follows: $i$ ) by comparing the presence or absence of the disease on each individual genotype and ii) comparing the presence or absence of the disease between each genotypes in the presence and absence of fungicide.

Table 2. Effect of the presence or absence of Fusarium head blight, chemical treatment and genotypes of oat on grain weight produced (yield)

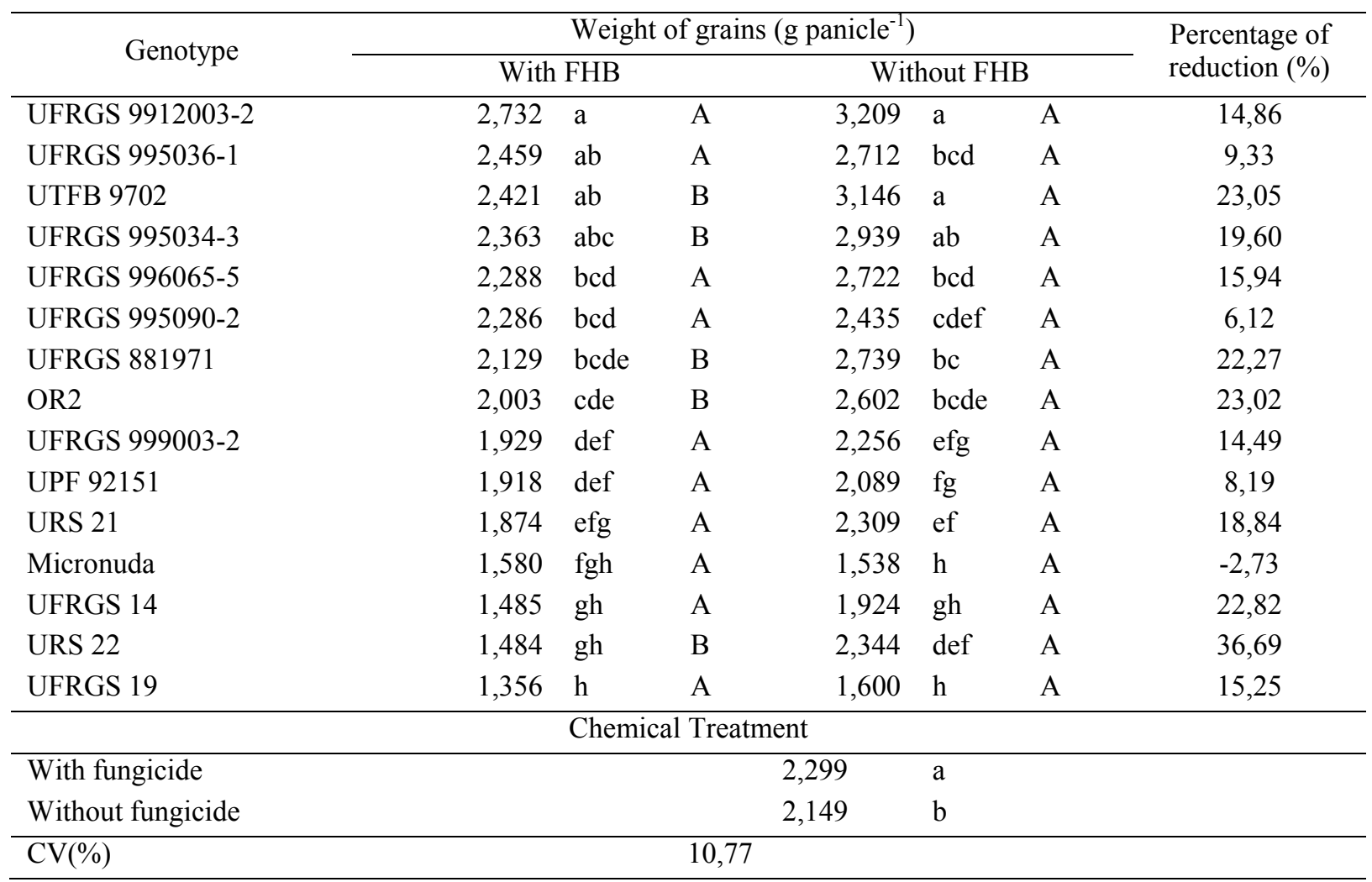

Means followed by the same letter are not significantly different at the .05 level by the Tukey's Test.

Lowercase letters indicate comparisons between genotypes for each situation: with and without FHB; and at the bottom of table, also indicate comparisons between treatments with and without fungicide.

Uppercase letters indicate comparisons between the two situations: with and without FHB for each genotype. 
No genotype showed complete immunity to FHB even with application of fungicide (Table 3). For plants treated with fungicide, the percentage of infected spikelets per panicle ranged from $3.07 \%$ for cultivar OR 2 to $6.75 \%$ for UFRGS 19 (Table 3). Without fungicide, the percentage of infected spikelets per panicle ranged from $3.94 \%$ for genotype UFTB 9702 to $7.68 \%$ for UFRGS 14 . Most genotypes showed a significantly lower level of FHB when treated with fungicide (Table 3 ).

We found no significant interaction between genotypes and fungicide treatment regarding potential yield $(\mathrm{P}>\mathrm{F}=0.20)$, observed yield $(\mathrm{P}>\mathrm{F}=0.192)$ and potential damage $(\mathrm{P}>\mathrm{F}=0.063)$, with only their simple effects being significant $(\mathrm{P}>\mathrm{F}=0.001)$ (Table 4). Differences between treatments were significant by Tukey's test at $\mathrm{P}=5 \%$. Applicable comparisons were made only for the simple effects of both genotypes and fungicide treatment. Genotypes UFRGS 9912003-2, UFRGS 995036-1, UFTB 9702, UFRGS 995034-3, UFRGS 996065-5 and UFRGS 995090-2 showed higher potential and observed yields whereas genotypes UFRGS 19, URS 22, UFRGS 14 and Micronuda showed lower values.

Fungicide application significantly influenced the potential yield of treated panicles (mean $=2.154 \mathrm{~g}$ per panicle) in relation to the untreated panicles (2.004 g per panicle) (Table 4). In addition, the observed yield ( $2.092 \mathrm{~g}$ panicle $\left.^{-1}\right)$ for panicles treated with fungicide was significantly higher than the observed yield (1.938 $\left.\mathrm{g} \mathrm{panicle}^{-1}\right)$ for untreated panicles. However, treatment with fungicide did not reduce the potential damage to the treated genotypes, with the mean percentage grain weight reduction being close to $3 \%$ for both treated and untreated plants (Table 4).

Table 3. Percentage of spikelets infected by Fusarium head blight in oat genotypes with and without fungicide treatment

\begin{tabular}{|c|c|c|c|c|c|c|}
\hline \multirow{2}{*}{ Genotype } & \multicolumn{6}{|c|}{ Spikelets infected by Fusarium (\%) } \\
\hline & \multicolumn{3}{|c|}{ With fungicide } & \multicolumn{3}{|c|}{ Without fungicide } \\
\hline UFRGS 996065-5 & 5,92 & $\mathrm{ab}$ & B & 7,59 & $\mathrm{ab}$ & A \\
\hline URS 21 & 5.65 & $\mathrm{bc}$ & B & 7,62 & $a b$ & A \\
\hline UFRGS 995090-2 & 5.60 & bcd & A & 4,46 & fg & B \\
\hline UFRGS 995036-1 & 4,41 & de & A & 4,22 & g & A \\
\hline URS 22 & 5,26 & bcd & B & 6,72 & $\mathrm{bc}$ & A \\
\hline UFRGS 19 & 6,75 & $\mathrm{a}$ & A & 6,68 & $\mathrm{bc}$ & A \\
\hline UFRGS 995034-3 & 3,81 & efg & B & 4,70 & fg & A \\
\hline Nuda Baixa & 4,00 & ef & B & 6,31 & $\mathrm{~cd}$ & A \\
\hline UPF 92151 & 4,53 & cde & B & 5,14 & ef & A \\
\hline UFRGS 999003-2 & 3,51 & efg & B & 5,90 & de & A \\
\hline UFRGS 9912003-2 & 3,29 & fg & B & 4,31 & $\mathrm{fg}$ & A \\
\hline UFRGS 14 & 5,42 & $\mathrm{bc}$ & B & 7,68 & $\mathrm{a}$ & A \\
\hline OR 2 & 3,07 & g & B & 5,79 & de & A \\
\hline UFRGS 881971 & 3,08 & fg & B & 5,74 & de & A \\
\hline UTFB 9702 & 3,37 & $\mathrm{fg}$ & B & 3,94 & $\mathrm{~g}$ & A \\
\hline
\end{tabular}

Means followed by the same letter are not significantly different at the .05 level by the Tukey's Test.

Lowercase letters indicate comparisons between genotypes for each situation: with and without fungicide.

Uppercase letters indicate comparisons between the two situations: with and without fungicide for each genotype.

Original data were transformed into arcsin values.

The greatest potential FHB damage was observed for genotypes UFRGS 996065-5 (0.111 $\mathrm{g}$ panicle $\left.^{-1}\right)$ and URS 21 $\left(0.088 \mathrm{~g} \mathrm{panicl}^{-1}\right)$. The lowest values of potential damage $\left(0.041 \mathrm{~g}\right.$ panicle $^{-1}$ to $0.069 \mathrm{~g}$ panicle $\left.^{-1}\right)$ were shown by 13 of the 15 genotypes tested.

Potential damage due to FHB did not correlate with the potential yield of the genotypes (Pearson correlation coefficient $0.21 \mathrm{P}=0.45$ ), indicating that the genotypes were evenly distributed between quartiles (Figure 2). 
Genotypes OR2, UFRGS 881971, UFTB 9702 and UFRGS 995034-3 grouped in quartile D, showing that they experienced less damage and had higher potential yields.

Table 4. Potential yield, observed yield and potential damage of Fusarium head blight on oat genotypes

\begin{tabular}{|c|c|c|c|c|c|c|c|}
\hline \multirow{2}{*}{$\begin{array}{l}\text { Genotypes } \\
\text { UFRGS 9912003-2 }\end{array}$} & \multicolumn{2}{|c|}{$\begin{array}{l}\text { Potential Yield } \\
\text { (g/panicle) }\end{array}$} & \multicolumn{2}{|c|}{$\begin{array}{c}\text { Observed Yield } \\
\text { (g/panicle) }\end{array}$} & \multicolumn{2}{|c|}{$\begin{array}{l}\text { Potential Damage } \\
(\mathrm{g} / \text { panicle })\end{array}$} & \multirow{2}{*}{$\begin{array}{c}\begin{array}{c}\text { Potential Damage } \\
(\%)\end{array} \\
2,46\end{array}$} \\
\hline & 2,801 & $\mathrm{a}$ & 2,732 & $\mathrm{a}$ & 0,069 & bcd & \\
\hline UFRGS 995036-1 & 2,523 & $\mathrm{ab}$ & 2,459 & $\mathrm{ab}$ & 0,064 & bcd & 2,54 \\
\hline UFTB 9702 & 2,479 & $a b c$ & 2,422 & $a b c$ & 0,057 & bcd & 2,30 \\
\hline UFRGS 995034-3 & 2,404 & abcd & 2,363 & abcd & 0,041 & $\mathrm{~d}$ & 1,71 \\
\hline UFRGS 996065-5 & 2,399 & abcd & 2,288 & abcd & 0,111 & $\mathrm{a}$ & 4,63 \\
\hline UFRGS 995090-2 & 2,363 & abcd & 2,286 & abcd & 0,077 & bc & 3,26 \\
\hline UFRGS 881971 & 2,188 & bcd & 2,130 & bcd & 0,058 & bcd & 2,65 \\
\hline OR 2 & 2,056 & bcde & 2,003 & bcde & 0,052 & $\mathrm{~cd}$ & 2,53 \\
\hline UFRGS 999003-2 & 1,982 & cdef & 1,929 & cdef & 0,053 & $\mathrm{~cd}$ & 2,67 \\
\hline UFP 92151 & 1,962 & def & 1,918 & cdef & 0,059 & bcd & 3,01 \\
\hline URS 21 & 1,962 & def & 1,874 & def & 0,088 & $a b$ & 4,49 \\
\hline Micronuda & 1,633 & efg & 1,580 & efg & 0,053 & $\mathrm{~cd}$ & 3,25 \\
\hline UFRGS 14 & 1,548 & efg & 1,485 & fg & 0,063 & bcd & 4,07 \\
\hline URS 22 & 1,544 & fg & 1,485 & fg & 0,060 & bcd & 3,89 \\
\hline UFRGS 19 & 1,416 & $\mathrm{~g}$ & 1,356 & g & 0,060 & bcd & 4,24 \\
\hline \multicolumn{8}{|l|}{ Chemical Treatment } \\
\hline With fungicide & 2,154 & $\mathrm{~A}$ & 2,092 & $\mathrm{~A}$ & 0,061 & $\mathrm{~A}$ & 2,83 \\
\hline Without fungicide & 2,004 & B & 1,938 & B & 0,066 & A & 3.29 \\
\hline CV (\%) & 11,80 & & 12.19 & & 24.54 & & \\
\hline
\end{tabular}

Means followed by the same letter are not significantly different at the .05 level by the Tukey's Test.

Lowercase letters indicate comparisons between genotypes. Uppercase letters indicate comparisons between treatments with and without fungicide.

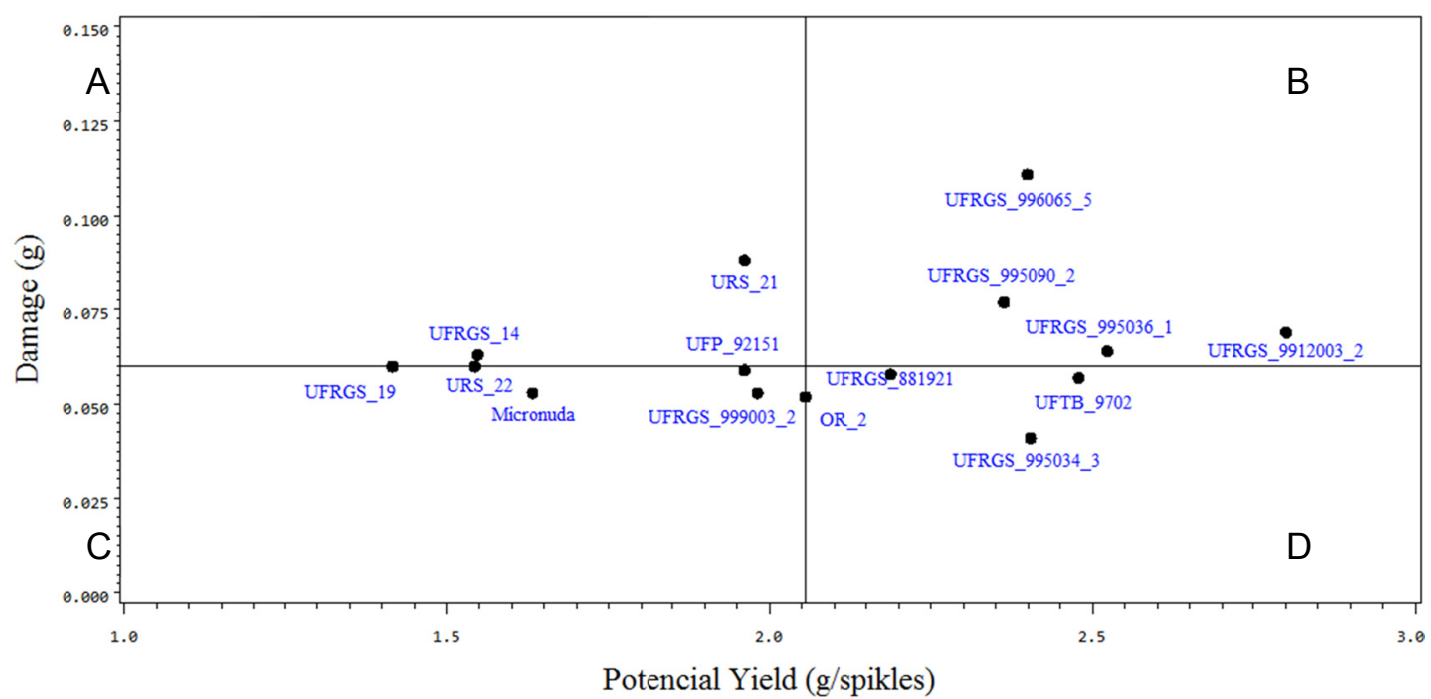

Figure 2. Biplot graphic illustrating the relationship between damage and potential yield of oat cultivars subdivided into quartiles based on the median value, where quartile A shows high damage and reduced yield potential; quartile B high damage and yield potential; quartile $\mathrm{C}$ reduced damage and yield potential; and quartile $\mathrm{D}$ reduced damage and high yield potential 


\section{Discussion}

Since no oat cultivars are immune to scab, with most oat cultivars being classified as susceptible or moderately resistant, accurate methods for screening genotypes regarding their sensibility to disease impacts are desirable tools for improving breeding efficiency.

We evaluated oat grain yield loss produced by FHB in some oat genotypes in order to assess the possibility of using panicle yield to differentiate levels of resistance in these genotypes. Although the environmental conditions in September 2003 were unfavorable for the occurrence of FHB (Figure 1A), September 2004 was humid and rainy and therefore very favorable to FHB (Figure 1B). These fortuitous environmental conditions do not often occur during experimental trials and, as such, the data obtained from this year is very valuable for determining the damage accruing to reduced oat grain weight.

The significant reduction in grain weight of between $19.60 \%$ and $36.69 \%$ found in our study for some genotypes is in accordance with the results reported by Mielniczuk, Kiecana, and Perkowski (2004), who observed reductions of between $10 \%$ and $37 \%$ in the weight of panicles inoculated with Fusarium crookwellense.

As expected, application of fungicide resulted in a greater grain weight per panicle due to the decrease in infected spikelets (Table 3). However, genotypes UFRGS 19 and UFRGS 995036-1 did not respond to treatment with fungicide, possibly because these two genotypes showed variation in the timing of anthesis, which may have lowered the efficiency of the fungicide treatment. Oat plants are known to show uneven anthesis, which starts at the apical spikelet and ends at the basal spikelets of the panicle about 8 to 10 days later (Rajala \& Peltonen-Sainio, 2011). This feature of oat flowering may have introduced a small level of uncontrolled variability in the results for genotypes UFRGS 19 and UFRGS 995036-1. In contrast, genotype UFRGS 995090-2 showed a higher incidence of infected spikelets when treated with fungicide (Table 3), possibly due to variation in the exposure of anthers of this genotype during flowering. This could have compromised the effectiveness of the fungicide and explain our result with this genotype, although we saw no variation in anther exposure when this genotype was sprayed.

Variation in resistance may well exist within oat genotypes, particularly with respect to routes of pathogen penetration. Since anthers are the primary infection route for FHB (Pugh et al., 1933; Strange \& Smith, 1971), genotypes that release their anthers in a shorter period of time reduce the period of infection and tend to be more resistant under natural conditions and are thus at lower risk of FHB (Teckle et al., 2012).

Although little is known for oats, in wheat it has been shown that retained anthers are more densely colonized by $F$. culmorum hyphae and that inoculated wheat heads are invaded at other easily penetrable parts of the floret regardless of the presence or absence of anthers (Kang \& Buchenauer, 2000). Furthermore, wheat genotypes showing higher levels of anther extrusion tended to develop less FHB and had lower levels of deoxynivalenol (DON) contamination (Skinnes, Semagn, Tarkegne, Maroy, \& Bjornstad, 2010). However, other reports have not confirmed this and the role of anthers is still regarded as equivocal (Engle, Lipps, Graham, \& Boehm, 2004). As indicated by the relatively low decrease in yield, the level of infection in our study was low and it is reasonable to suppose that the level of DON would also be low, although work is required to support this.

We defined potential damage as a reduction in yield, expressed as a reduction in the weight of the oat grains produced. The potential FHB damage reported in this paper varied between $1.71 \%$ and $4.63 \%$, with the mean reduction in yield for the 15 genotypes being 3.19\%. These results are low when compared with FHB damage reported for crops such as rye (43.9\%), wheat (17.5\%) and barley (8.3\%) (Panisson et al., 2003). The reason for this may be that oat plants show effective Type II resistance due to the long, widely-spaced, pedicels separating individual spikelets in a panicle, making the spread of disease between spikelets difficult. Hence, single infections may be less destructive in oats due to the spike morphology. However, high yield losses of up to $32 \%$ in field experiments involving oats in Poland have been reported (Mielniczuk et al., 2004), although in this case the plants were inoculated artificially with Fusarium in the field, which may have resulted in an overestimation of the potential damage of the disease. The relationship between potential damage and the potential yield among the 15 oat genotypes was compared by plotting these two variables on a biplot graph which indicated that the genotypes were evenly distributed between quartiles (Figure 2).

The data presented in this paper suggest the existence of genetic variation in oat with respect to the damage produced by FHB. Such damage, however, is relatively low compared to other cereals such as wheat or barley (Panisson et al., 2003; Tekauz, McCallum, Ames, \& Mitchell Fetch, 2004; Tekauz et al., 2008). Damage was low in our experiments even considering that they were carried out in 2004, a year which was especially favourable for oat FHB. In addition to the long pedicels described above, a further factor which may explain our results is that oat panicles have widely-spaced spikelets, which is very different to the architecture found in wheat or barley 
(Bjørnstad \& Skinnes, 2008; Kosová, Chrpová, \& Šíp, 2009). This could lead to a large reduction in the spread of FHB to surrounding spikelets and the rachis (Tekle, Dill-Macky, Skinnes, Tronsmo, \& Bjørnstad, 2012).

To our knowledge, this is the first paper presenting field-data showing relatively small grain weight losses due to FHB. Among the oat genotypes tested, there was no genotype with complete immunity to FHB. As mentioned in the results, genotypes OR2, UFRGS 881971, UFTB 9702 and UFRGS 995034-3 were grouped in quartile D, indicating that they were subjected to lower levels of damage and had higher potential yields because they were more resistant to FHB than the other genotypes. These results indicate that our methodology is very useful for screening genotypes regarding their sensibility to FHB and is thus a desirable tool for improving breeding efficiency in oats. The use of continuous no-tillage and the low level of control by fungicides may mean that FHB could increase in importance and therefore should be carefully monitored in the field.

\section{References}

Angelotti, F., Tessmann, D. J., Alves, T. C. A., Vida, J. B., Jaccoud Filho, D. S., \& Harakava, R. (2006). Morphological characterization and molecular identification of Fusarium graminearum isolates associated with Fusarium head blight in wheat and triticale in Southern Brazil. Summa Phytopathologica, 32, 177-179. http://dx.doi.org/10.1590/S0100-54052006000200013

Bergamaschi, H., Guadagnin, M. R., Cardoso, L. S., \& Silva, M. I. G. da. (2003). Clima da estação experimental da UFRGS e região de abrangência. UFRGS, Porto Alegre, RS, Brazil.

Bjørnstad, A., \& Skinnes, H. (2008). Resistance to Fusarium infection in oats (Avena sativa L.). Cereal Research Communications, 36, 57-62. http://dx.doi.org/10.1556/CRC.36.2008.Suppl.B.9

Brown, N. A., Urban, M., Van de Meene, A. M. L., \& Hammond-Kosack, K. E. (2010). The infection biology of Fusarium graminearum: Defining the pathways of spikelet to spikelet colonization in wheat ears. Fungal Biology, 114, 555-571. http://dx.doi.org/10.1016/j.funbio.2010.04.006

Casa, R. T., Reis, E. M., Severo, R., Denti, E., Trento, S., \& Blum, M. M. C. (2000). Prevenção e controle de doenças na cultura do milho. In I. E. Sandini, \& A. L. Fancelli (Eds.), Milho: estratégias de manejo para a região sul. Guarapuava: Fundação Agrária de Pesquisa Agropecuária (pp. 131-146).

EMBRAPA (Empresa Brasileira de Pesquisa Agropecuária). (1990). Programa SOC - Software Científico, Versão 2.1. Campinas: Embrapa Informática Agropecuária.

Engle, J. S., Lipps, P. E., Graham, T. L., \& Boehm, M. J. (2004). Effects of choline, betaine, and wheat floral extracts on growth of Fusarium graminearum. Plant Disease, 88, 175-180. http://dx.doi.org/10.1094/PDIS.2004.88.2.175

Fernandez, M. R., Fernandes, J. M., \& Sutton, J. C. (1993). Effects of fallow and of summer and winter crops on survival of wheat pathogens in crop residues. Plant Disease, 77, 698-703. http://dx.doi.org/10.1094/PD-77-0698

Goswami, R. S., \& Kistler, H. C. (2004). Heading for disaster: Fusarium graminearum on cereal crops. Molecular Plant Pathology, 5, 515-525. http://dx.doi.org/10.1111/j.1364-3703.2004.00252.x

Kang, Z. S., \& Buchenauer, H. (2000). Cytology and ultrastructure of the infection of wheat spikes by Fusarium culmorum. Mycological Research, 104, 1083-1093. http://dx.doi.org/10.1017/S0953756200002495

Kosová, K., Chrpová J., \& Šíp, V. (2009). Cereal resistance to Fusarium Head Blight and possibilities of its improvement through breeding. Czech Journal of Genetics and Plant Breeding, 45, 87-105. http://www.cabdirect.org/abstracts/20093309985.html

Mauler-Machnik, A., \& Zahn, K. (1994). Ear fusarioses in wheat - new findings on their epidemiology and control with Folicur (tebuconazole). Pflanzenschutz-Nachrichten Bayer, 47, 129-155.

McMullen, M. P., Jones, R. K., \& Gallenberg, D. J. (1997). Scab of wheat and barley - A re-emerging disease of devastating impact. Plant Disease, 81, 1340-1348. http://dx.doi.org/10.1094/PDIS.1997.81.12.1340

Mesterházy, Á., \& Bartók, T. (1996). Control of Fusarium head blight of wheat by fungicides and its effect on the toxin contamination of the grains. Pflanzenschutz-Nachrichten Bayer, 49, 181-198.

Mielniczuk, E., Kiecana, I., \& Perkowski, J. (2004). Susceptibility of oat genotypes to Fusarium crookwellense Burgess, Nelson and Toussoun infection and mycotoxin accumulation in kernels. Biologia Bratislava, 59, 809-816. 
Panisson, E., Reis, E. M., \& Boller, W. (2003). Quantificação de danos causados pela Giberela em cereais de inverno, na safra 2000, em Passo Fundo, RS. Fitopatologia Brasileira, 28, 189-192. http://dx.doi.org/10.1590/S0100-41582003000200013

Parry, D. W., Jenkinson, P., \& McLeod, L. (1995). Fusarium ear blight (scab) in small grain cereals - a review. Plant Pathology, 44, 207-238. http://dx.doi.org/10.1111/j.1365-3059.1995.tb02773.x

Pereyra, S., \& Dill-Macky, R. (2010). Fusarium species recovered from wheat and barley grains in Uruguay, pathogenicity and deoxynivalenol content. Agrociencia Uruguay, 14, 33-44.

Pirgozliev, S. R., Edwards, S. G., Hare, M. C., \& Jenkinson, P. (2003). Strategies for the control of Fusarium head blight in cereals. European Journal of Plant Pathology, 109, 731-742. http://dx.doi.org/10.1023/A:1026034509247

Pugh, G. W., Johann, H., \& Dickson, J. G. (1933). Factors affecting infection of wheat heads by Gibberella saubinetti. Journal of Agriculatural Research, 46, 771-797.

Rajala, A., \& Peltonen-Sainio, P. (2011). Pollination dynamics, grain weight and grain cell number within the inflorescence and spikelet in oat and wheat. Agricultural Science, 2, 283-290. http://dx.doi.org/10.4236/as.2011.23037

Reis, E. M. (1986). Metodologia para a determinação de perdas causadas em trigo por Gibberella zeae. Summa Phytopathologica, 11, 951-955.

Reis, E. M., Panisson, E., \& Boller, W. (2002). Efeito de época, do número de aplicações e de doses de fungicidas no controle da gibelea em trigo. Fitopatologia Brasileira, 27, 495-499. http://dx.doi.org/10.1590/S0100-41582002000500010

Silva, M. R. da, Martinelli, J. A., Federizzi, L. C., Chaves, M. S., \& Pacheco, M. T. (2012). Lesion size as a criterion for screening oat genotypes for resistance to leaf spot. European Jounal of Plant Pathology, 134, 315-327. http://dx.doi.org/10.1007/s10658-012-9991-7

Skinnes, H., Semagn, K., Tarkegne, Y., Maroy, A. G., \& Bjornstad, A. (2010). The inheritance of anther extrusion in hexaploid wheat and its relationship to Fusarium head blight resistance and deoxynivalenol content. Plant Breeding, 129, 149-155. http://dx.doi.org/10.1111/j.1439-0523.2009.01731.x

Strange, R. N., \& Smith, H. (1971). A fungal growth stimulant in anthers which predisposes wheat to attack by Fusarium graminearum. Physiological Plant Pathology, 1, 141-150. http://dx.doi.org/10.1016/0048-4059(71)90023-3

Strange, R. N., Majer, J. R., \& Smith, H. (1974). The isolation and identification of choline and betaine as the two major components in anthers and wheat germ that stimulate Fusarium graminearum in vitro. Physiological Plant Pathology, 4, 277-290. http://dx.doi.org/10.1016/0048-4059(74)90015-0

Streck, E. V., Kampf, N., Dalmolin, R. S. D., Klamt, E., Nascimento, P. C., \& Schnetder, P. (2002). Solos do Rio Grande do Sul. Porto Alegre, Universidade Federal do Rio Grande do Sul.

Tamburic-Ilincic, L. (2010). Fusarium species and mycotoxins associated with oat in southwestern Ontario, Canada. Canadian Journal of Plant Science, 90, 211-216. http://dx.doi.org/10.4141/CJPS09139

Tekauz, A., McCallum, B., Ames, N., \& Mitchell Fetch, J. W. (2004). Fusarium head blight of oat: Current status in western Canada. Canadian Journal of Plant Pathology, 26, 473-479. http://dx.doi.org/10.1080/07060660409507167

Tekauz, A., Mitchell Fetch, J. W., Rossnagel, B. G., \& Savard, M. E. (2008). Progress in assessing the impacy of Fusarium head blight on oat in western Canada and screening of Avena germplasm for resistance. Cereal Research Communications, 36, 49-56. http://dx.doi.org/10.1556/CRC.36

Tekle, S., Dill-Macky, R., Skinnes, H., Tronsmo, A. M., \& Bjørnstad, A. (2012). Infection process of Fusarium graminearum in oats (Avena sativa L.). European Journal of Plant Pathology, 132, 431-442. http://dx.doi.org/10.1007/s10658-011-9888-x

Tekle, S., Skinnes, H., \& Bjørnstad, Å. (2013). The germination problem of oat seed lots affected by Fusarium head blight. European Journal of Plant Pathology, 135, 147-158. http://dx.doi.org/10.1007/s10658-012-0074-6

Yli-Mattila, T. (2010). Ecology and evolution of toxigenic Fusarium species in cereals in northern Europe and Asia. Journal of Plant Pathology, 92, 7-18. http://dx.doi.org/10.4454/jpp.v92i1.10 
Zadoks, J. C., Chang, T. T., \& Konzak, C. F. (1974). A decimal code for the growth stages of cereals. Weed Research, 14, 415-421. http://dx.doi.org/10.1111/j.1365-3180.1974.tb01084.x

\section{Copyrights}

Copyright for this article is retained by the author(s), with first publication rights granted to the journal.

This is an open-access article distributed under the terms and conditions of the Creative Commons Attribution license (http://creativecommons.org/licenses/by/3.0/). 